\title{
Preovulatory changes in ovarian cyclic AMP and prostaglandins in immature rats injected with PMSG
}

\author{
S. Bauminger, Y. Koch, I. Khan*, T. Hillensjö*, L. Nilsson* and \\ K. Ahrén* \\ Department of Hormone Research, The Weizmann Institute of Science, \\ Rehovot, Israel, and *Department of Physiology, University of Göteborg, Göteborg, Sweden
}

Summary. In 28-day-old rats injected with PMSG, ovarian cyclic AMP and PGE and PGF increased 2 and 3-4 h respectively after the LH peak.

Cyclic AMP and prostaglandins are believed to be involved in the action of LH on ovarian follicles in mammals. Cyclic AMP has been implicated as a mediator of the LH effect on luteinization (Kolena \& Channing, 1972) and on ovum maturation (Tsafriri, Lindner, Zor \& Lamprecht, 1972a), whereas prostaglandins (PGs) have been implicated in follicular rupture. Thus, indomethacin, an inhibitor of prostaglandin synthetase, blocks the $\mathrm{LH}$-induced ovulation in rats and rabbits and this blockage can be overcome by PGE-2 (Armstrong \& Grinwich, 1972; Tsafriri et al., 1972b). Moreover, follicular levels of PGE and PGF increase around the time of ovulation in the rabbit (Armstrong, Moon \& Grinwich, 1972; Marsh, Yang \& LeMaire, 1974) and rat (Bauminger \& Lindner, 1975).

In a previous report (Nilsson, Rosberg, Hillensjö \& Ahrén, 1975) we have shown that in immature rats injected with PMSG there is a transient elevation of ovarian cyclic AMP on the day before ovulation. The aim of the present study was to clarify the relationship between the levels of serum LH, ovarian cyclic AMP, PGE and PGF during the periovulatory period in immature rats injected with PMSG.

\section{Methods}

Immature Sprague-Dawley rats maintained under standardized environmental conditions (light 05:00-19:00 h;22 $\pm 1^{\circ} \mathrm{C}$ ) were injected s.c. with 8 i.u. PMSG (NIAMDD-PMSG-2) on the morning of Day 28 of age. This treatment results in the ovulation of $12 \pm 2$ (s.e.m.) ova between 02:00 and 05:00 h on Day 31 (Herlitz, Koch, Khan \& Ahrén, 1976). At different times on Days 30 and 31 (see Table 1) the animals were killed by decapitation and the trunk blood was collected for LH determination. The limits of the time intervals were chosen to give at least 5 animals in each group. The ovaries were placed in ice-chilled $\mathrm{NaCl}$ and trimmed of extraneous tissue. The tissue was then weighed, frozen in Frigen II and stored at $-20^{\circ} \mathrm{C}$ until analysed. Ovarian cyclic AMP in one ovary was determined by the protein-binding technique of Gilman (1970) and protein content by the method of Lowry, Rosebrough, Farr \& Randall (1951). PGE and PGF in the other ovary of each animal were analysed by radioimmunoassay as described previously (Bauminger, Lieberman \& Lindner, 1975). Serum LH was determined by radioimmunoassay with a kit obtained from the Rat Pituitary Program of the National Institute of Arthritis Metabolism and Digestive Diseases (NIAMDD). The values are expressed in terms of ng NIAMDD-RP-1/ml and the detection limit was $100 \mathrm{ng} / \mathrm{ml}$. Statistical analysis was performed with Student's $t$ test or with analysis of variance (with one criterion of classification) followed by the Student-Newman-Kuel's test. A $P$ value less than 0.05 was considered significant.

\section{Results}

The results are summarized in Table 1. Administration of PMSG to 28-day-old rats elicited an LH surge on the afternoon of Day 30, which was soon followed by an increase in ovarian cyclic AMP. The rise in ovarian PGE and PGF content occurred 3-4 h after the initial increase in serum LH levels and reached peak levels shortly before ovulation. 
Table 1. Periovulatory changes (mean \pm s.e.m., no. of animals in parentheses) in serum LH, ovarian cyclic AMP levels, and ovarian PGE and PGF levels in immature rats treated with PMSG

\begin{tabular}{|c|c|c|c|c|}
\hline Time (h) & $\begin{array}{c}\text { LH } \\
(\mathrm{ng} / \mathrm{ml})\end{array}$ & $\begin{array}{c}\text { cAMP } \\
\text { (pmol/mg protein) }\end{array}$ & $\begin{array}{c}\text { PGE } \\
\text { (pg/mg ovary) }\end{array}$ & $\begin{array}{c}\text { PGF } \\
\text { (pg/mg ovary) }\end{array}$ \\
\hline \multicolumn{5}{|l|}{ Day 30} \\
\hline $12: 00-14: 00$ & (11) $108 \pm 4$ & (10) $31 \cdot 5 \pm 1 \cdot 4$ & (9) $79 \pm 5$ & (9) $122 \pm 16$ \\
\hline $14: 00-16: 00$ & (15) $171 \pm 42$ & (14) $33.6 \pm 1.7$ & (5) $82 \pm 13$ & \\
\hline $16: 00-17: 00$ & (16) $338 \pm 72 * \dagger$ & (15) $37.9 \pm 2.8$ & (6) $66 \pm 6$ & (8) $120 \pm 12$ \\
\hline $17: 00-18: 00$ & (10) $305 \pm 53^{*}$ & (16) $39.8 \pm 2.6^{*} \dagger$ & (6) $108 \pm 18$ & (10) $137 \pm 20$ \\
\hline $18: 00-19: 00$ & (16) $484 \pm 97^{*}$ & (16) $43.9 \pm 4.5^{*}$ & (16) $159+22^{*}+$ & (9) $195+22^{*} t$ \\
\hline $19: 00-20: 00$ & - & (6) $42 \cdot 7 \pm 4 \cdot 0^{*}$ & (10) $159 \pm 22^{\circ} \mathrm{T}$ & (9) $190 \pm 22 \mathrm{~T}$ \\
\hline $21: 00-23: 00$ & (11) $216 \pm 35^{*}$ & (11) $36.0 \pm 2.8$ & (6) $200 \pm 14^{*}$ & 一 \\
\hline $23: 00-01: 00$ & & (6) $36.9 \pm 1.6$ & (10) $304 \pm 48^{*}$ & (10) $210 \pm 29^{*}$ \\
\hline \multicolumn{5}{|l|}{ Day 31} \\
\hline 02:00-04:00 & (6) $111 \pm 5$ & (5) $33.3 \pm 2 \cdot 4$ & (11) $147 \pm 20^{*}$ & (11) $173 \pm 18^{*}$ \\
\hline $04: 00-07: 00$ & (6) $106 \pm 5$ & (12) $29 \cdot 7 \pm 1 \cdot 2$ & (11) $101 \pm 14$ & (11) $138 \pm 14$ \\
\hline $07: 00-09: 00$ & below 100 & - & (11) $75 \pm 7$ & (10) $146 \pm 11$ \\
\hline
\end{tabular}

* These values were significantly different $(P<0.05)$ from the corresponding ones at 12:00-14:00 h (analysis of variance).

$\dagger$ These values represent the first significant $(P<0.02)$ elevation from the 12:00-14:00 h value (Student's $t$ test).

\section{Discussion}

Changes in ovarian PG content around the time of ovulation have previously been reported for the rabbit (LeMaire \& Marsh, 1975) and the adult rat (Bauminger \& Lindner, 1975). In the rat, the preovulatory increase in ovarian cyclic AMP is moderate (less than $40 \%$ ), but it reflects changes in the cyclic AMP content of the whole ovarian tissue, and it is reasonable to assume, therefore, that the increase in cyclic AMP levels of the ovarian cells that contain LH-receptors is more pronounced. Cyclic AMP levels had declined by the time of ovulation and there was no evidence for a second peak, as observed in the rabbit ovary after hCG administration (Goff \& Major, 1975).

Our observation that the rise in ovarian cyclic AMP seems to precede that of prostaglandins is in accordance with data obtained from in-vitro experiments on preovulatory follicles in which it was shown that LH stimulates cyclic AMP formation within minutes (Lamprecht, Zor, Tsafriri \& Lindner, 1973; Marsh et al., 1974; Nilsson, Rosberg \& Ahrén, 1974) whereas PG synthesis is elevated only after several hours (Marsh et al., 1974; Yang, Marsh \& LeMaire, 1974; Bauminger \& Lindner, 1975). This is, however, the first study in which the levels of LH, cyclic AMP and PG in vivo have been simultaneously examined. The present results and those of others makes it unlikely that PGs are mediators of LH action on follicular cyclic AMP production, as suggested by Kuehl, Humes, Tarnoff, Cirillo \& Ham (1970), although prostaglandins are capable of stimulating ovarian cyclic AMP formation in vitro (Zor et al., 1973; Nilsson et al., 1974). Marsh et al. (1974) have shown that cyclic AMP added to slices of rabbit ovaries in vitro can stimulate PG formation, and our results support their conclusions that the increase in ovarian cyclic AMP levels caused by LH triggers the synthesis of PGs by the ovary.

This work was supported by grants from the Ford Foundation and Population Council, Inc., (to H. R. Lindner), the Medical Faculty, University of Göteborg, Göteborg, Sweden, Harald Jeanssons Stiftelse and Magnus Bergvalls Stiftelse.

\section{References}

Armstrong, D.T. \& Grinwich, D.L. (1972) Blockade of spontaneous and $\mathrm{LH}$-induced ovulation in rats by indomethacin, an inhibitor of prostaglandin biosynthesis. Prostaglandins 1, 21-36.
Armstrong, D.T., Moon, Y.S. \& Grinwich, D.L. (1972) Possible role of prostaglandins in ovulation. Adv. Biosci. 9, 709-715.

Bauminger, S. \& Lindner, H.R. (1975) Periovulatory 
changes in ovarian prostaglandin formation and their hormonal control in the rat. Prostaglandins 9, 737-751.

Bauminger, S., Lieberman, M.E. \& Lindner, H.R. (1975) Steroid-independent effect of gonadotrophins on prostaglandin synthesis in rat Graafian follicles in vitro. Prostaglandins 9, 753-764.

GilmAN, A.G. (1970) A protein binding assay for adenosine 3,5-cyclic monophosphate. Proc. natn. Acad. Sci. USA 67, 305-310.

GoFF, A.K. \& MAJOR, P.W. (1975) Concentrations of cyclic AMP in rabbit ovarian tissue during the preovulatory period and pseudopregnancy after induction of ovulation by administration of human chorionic gonadotrophin. J. Endocr. 65, 73-82.

HeRlitz, H., KOCH, Y., KHAN, M.I. \& AHRÉN, K. (1976) Effect of follicle-stimulating hormone on cyclic AMP levels in young corpora lutea of the rat. Eur. $J$. Obstet. Gynec. Reprod. Biol. 6, 175-179.

Kolena, J. \& Channing, C.P. (1972) Stimulatory effects of LH, FSH and prostaglandins upon cyclic 3,5-AMP levels in porcine granulosa cells. Endocrinology 90, 1543-1550.

Kuehl, F.A., JR, Humes, J.L., Tarnoff, J., Cirillo, V.J. \& HAM, E.A. (1970) Prostaglandin receptor site: evidence for an essential role in the action of luteinizing hormone. Science, N.Y. 169, 883886.

LAMPRECHT, S.A., ZoR, U., TSAFRIRI, A. \& LINDNER, H.R. (1973) Action of prostaglandin $E_{2}$ and of luteinizing hormone on ovarian adenylate cyclase, protein kinase and ornithine decarboxylase activity during postnatal development and maturity in the rat. J. Endocr. 57, 217-233.
LeMaIRE, W.J. \& Marsh, J.M. (1975) Interrelationships between prostaglandins, cyclic AMP and steroids in ovulation. J. Reprod. Fert., Suppl. 22, 53-74.

Lowry, O.H., Rosebrough, N.J., FarR, A.L. \& RANDALL, R.J. (1951) Protein measurement with the Folin phenol reagent. J. biol. Chem. 193, 265-275.

Marsh, J.M., YaNG, N.S.T. \& LeMatre, W.J. (1974) Prostaglandin synthesis in rabbit Graafian follicles in vitro. Effect of luteinizing hormone and cyclic AMP. Prostaglandins 7, 269-283.

Nilsson, L., Rosberg, S. \& Ahrén, K. (1974) Characteristics of the cyclic 3,5-AMP formation in isolated ovarian follicles from PMSG-treated immature rats after stimulation in vitro with gonadotrophins and prostaglandins. Acta endocr., Copenh. 77, 559-574.

Nilsson, L., Rosberg, S., Hillensjö, T. \& Ahrén, K. (1975) Preovulatory changes of ovarian cyclic AMP in the rat. Life Sci. 16, 517-524.

TSAFRIRI, A., LINDNER, H.R., ZOR, U. \& LAMPRECHT, S.A. (1972a) In vitro induction of meiotic division in follicle-enclosed rat oocytes by $\mathrm{LH}$, cyclic AMP and prostaglandin $\mathrm{E}_{2}$. J. Reprod. Fert. 31, 39-50.

TSAFRIRI, A., LINDNER, H.R., ZOR, U. \& LAMPRECHT, S.A. (1972b) Physiological role of prostaglandins in the induction of ovulation. Prostaglandins 2, 1-10.

YANG, N.S.T., MarSh, J.M. \& LeMaIRE, W.J. (1974) Postovulatory changes in the concentrations of prostaglandins in rabbit Graafian follicles. Prostaglandins $6,37-43$.

Zor, U., BAuminger, S., LAMPrecht, S.A., Koch, Y., Chobsieng, P. \& LindneR, H.R. (1973) Stimulation of cyclic AMP production in the rat ovary by luteinizing hormone: independence of prostaglandin mediation. Prostaglandins 4, 499-506.

Received 14 February 1977 